\title{
Service Delivery from a South African Police Service Perspective
}

\author{
John Modise
}

ORCiD ID: https://orcid.org/0000-0002-2350-0695

\author{
Derek Taylor \\ ORCiD ID: https://orcid.org/0000-0002-2524-0559
}

\author{
Kishore Raga \\ ORCiD ID: https://orcid.org/0000-0002-1548-2079
}

\section{Abstract}

In terms of section 205 (1); (2) and (3) of the Constitution of the Republic of South Africa, 1996, the South African Police Service is mandated to prevent, combat and investigate crime, maintain public order, protect and secure the inhabitants of the Republic and their property, and uphold and enforce the law. The Service Delivery Improvement Programme (SDIP) (in SAPS) endeavours to enhance service delivery to the communities (South African Police Service (SAPS 2006b:6-19). The programme provides police station commanders with practical tools to enhance service delivery and law enforcement while seeking to inculcate a culture of participative management and increased community involvement. This is embodied in the SAPS (SAPS 2006a) Service Delivery Improvement Programme (SDIP). The purpose of this article is to reflect on the findings of a recently completed $\mathrm{PhD}$ study, which aimed to investigate the expectations and perceptions of members of the public towards the South African Police Service (SAPS); as well as service delivery in the Community Service Centre (CSC) in the Kimberley Cluster, and to consider the implications of COVID-19. The focus of the study was based on the measurement of service quality dimension and service delivery to generate quality models for SAPS CSC. The primary objective was to develop an understanding of the client's expectations and perceptions of the services 
delivered by the SAPS CSC. The SERVQUAL Model was utilised to establish the clients' perceptions against their expectations of service quality at the SAPS CSC. The study was conducted in the SAPS environment, to contribute to customer citizenship behaviour, specifically the sub-dimensions of consumer advocacy and helping behaviour. The quantitative methodology was adopted to investigate the effect of customer satisfaction of service quality in the SAPS. A structured questionnaire was distributed to gather data. One (100) hundred respondents were surveyed. The data was analysed using Descriptive and Inferential statistics. The five service quality dimensions of the Servqual Model was utilised to measure the client's expectations and perceptions. The results revealed that in all five service quality dimensions: (tangibility, reliability, responsiveness, assurance and empathy); there was a negative quality gap. The significant differences between perception and expectations of the clients in all five service quality dimensions was noted. Improvement is needed across all five service quality dimensions to enhance service delivery. Furthermore, the results revealed that the client's perception of service quality at the SAPS CSC is up to standard. It is recommended that SAPS assess and monitor employees regularly, including the clients experiences and provide feedback.

Keywords: South African Police Service (SAPS), Service delivery, Customer satisfaction, Service quality, Clients, Servqual, Community Policing, Trust

\section{Introduction}

The South African Police Service (SAPS) leadership is facing challenges to enhance service delivery in the organisation. Various legislative and policy directives exist, but the implementation thereof has been a challenge. The SAPS' service delivery has been inadequate, and the media has reported on this regularly (The Daily Sun 2017). Furthermore, taxpayers, who are the financiers of government, increasingly want to find out more about the costeffectiveness of their tax money and whether police services are being delivered efficiently. Reasons for the apparent inadequate service delivery ranges from police members apathetic attitudes to a lack of training and skills (Burger 2013).

The legislative and policy framework promoting improved service de- 
livery in the South African Police Service has received limited attention. Leadership in the public service is not only about occupying important offices or ranks, but should also include the ability to be visionary, leadership skills, motivation of staff, and continuously striving to improve service delivery. Moreover, efforts directed at converting the SAPS to a post-bureaucratic organisation and introducing managerialism has not taken root thoroughly (Van der Merwe, Van Graan \& Ukpere 2013:630). Police stations are critical units in the police administration system. For many citizens, their first encounter with a police official is at a police station, to report a crime or seek assistance. The public's expectations of the police can only be met if they are satisfied with the professionalism and promptness of the services rendered by the officers at police stations. Therefore, it is important that SAPS personnel ren-der services of a high standard, with efficiency, professionalism, integrity and empathy. The term "enable" refers not only to the provision of equipment, which is important, but also to the provision of skills and training, which are equally important for ensuring that the needs of community members are prioritised.

Globally, all police agencies have a common purpose: deliver an effective service to the communities in which they are situated (Sonderling 2003:1). The SAPS too, in essence, stands for service delivery. This is underlined by the National Strategy (SAPS 2002a:6), which accentuates the significance to provide a quality service to its clients; the South African public. This conforms with its own mission as well as the government's strategy, which is clear when it comes to the purpose of service delivery. It further embodies the Service Delivery Improvement Programme (SDIP) of the SAPS (SAPS 2006a). The primary goal is to provide a service to the public (SAPS.a: 2006:78). The SAPS is considered an important government department due to the nature of the services it renders. Furthermore, it has its own policies, procedures, processes and systems, and for these to be implemented correctly within the organisation, personnel must have a clear understanding, knowledge and guidance about what is expected (South African Police Service (SAPS) 2006c:7-8). Concerns and contributions to service delivery must promote the interest of the communities they serve and quality service delivery is important for any service provider. Levels of trust is also important, especially in terms of law enforcement. When trust in communication channels and public participation strategies is limited, co-production of services is impeded, and the ability to increase such trust is, in turn, is affected negatively (Jakoet-Salie 2018). 


\section{Research Problem}

Complaints is a measure that can be used to measure the quality of service rendered by the South African Police Service. The aim is to amend service delivery based on the community's complaints. The Independent Police Investigative annual report for 2006/07 revealed that the South African Police Service received 5412 complaints against its members (Independent Police Investigative 2006/2007).

Northern Cape contributed 462 in this figure, which constitutes $9 \%$. The complaints generated by the Northern Cape was relatively high in comparison to provinces such as Eastern Cape, Mpumalanga and Limpopo which only contributed $7 \%$ and $8 \%$ respectively (SAPS 2014/19, Strategic Plan).

Of significance is that the Northern Cape is the least populated province in the country. It comprises of 1 million citizens compared to the above mentioned provinces which vary from 4 million to 7 million respectively (South African Police Service 2008). A preliminary investigation revealed that based on information presented in the preceding paragraphs, SAPS management and commanders are concerned with the quality of service delivery. Furthermore, there has been considerable speculation on the reasons for this apparent poor service. Most senior officers assume that the lack of discipline and the demilitarisation of the SAPS is responsible for the poor delivery of services. They believe that although police officers are competent, a professional service is not provided because it demands more effort and input. However, the level of this perceived poor service, the understanding of the concept of service and the reason for such (provided by SAPS) is a serious concern for the community.

\section{Literature Review \\ Theoretical Literature}

Services

Services have certain unique characteristics, which distinguish them from goods. A consumer cannot hold a service and look at it before purchasing. Therefore, service organisations often use messages and images in their 
promotional structure to help make the benefits of the service experience more tangible. Service customers often seek reviews and clues to help them judge the quality of a service before they buy. As a result, services underscore the physical evidence of quality (Perreault, Cannon \& McCarthy 2008; Lamb, Walstab, Teese, Vickers \& Rumberger 2004; Lewis \& Boom 1983). There are four service characteristics in service marketing, namely: intangibility; heterogeneous; inseparability from consumers; and perishability. These are expounded upon in the sections below.

\section{Intangibility}

Fitzsimmons and Fitzsimmons (2008:389) assert that services are not physical, they are intangible. When you provide a customer with a service, the customer cannot keep it. A service is experienced, used, or consumed. The services are performances or actions rather than objects; they cannot be seen, felt, tasted or touched in the same manner that you can sense tangible goods (Kotler 2000:429). Service cannot be patented easily, and new service concepts can, therefore, easily be copied by competitors.

Chowdhury and Prakash (2001:496) state that 'an intangible service may require the customer to be mentally or physically present to receive the service'.

Services cannot be seen, touched, tasted, felt or smelled in the same way as physical goods can be sensed. They cannot be inventoried or stored for long periods of time and they are difficult to duplicate. There are usually little or no tangible evidence once the service has been performed. Services are also more difficult to measure than physical products (Grönroos 1988; Kotler 2000; Lamb, Walstab, Teese, Vickers \& Rumberger 2004; Lewis \& Boom 1983; Palmer 2008).

\section{Heterogeneity}

Dhurup, Singh and Surujlal (2006:40) assert that quality of service performance is inconsistent and unpredictable. The employees delivering the service frequently are the same in the customer's eyes, and people may differ in their performance from day to day or even from hour-to-hour. Ensuring consistent service quality is challenging, because these are heterogeneous across time, organisations and people. Service is sometimes produced in person where the customer is located, and has committed to buy. It is difficult to 
achieve economies of scale with personal service. One of the reasons for this is that service suppliers need similar equipment and staff at places where the service is actually provided and where it is difficult to achieve (Fitzsimmon \& Fitzsimmon 2006:325).

Services tend to be less standardised and uniform than goods. Quality control and consistency are difficult to achieve because services are labour intensive and production and consumption are inseparable (Lamb, Walstab, Teese, Vickers \& Rumberger 2004; Lewis \& Boom 1983). Lewis (2007) posits that variability in services often exists because of non-standardisation of delivery. Standardisation and the training of service personnel may help to increase the quality control and consistency of the service delivery process because the staff will understand the customer's requirements and react appropriately (Ghobadian, Speller \& Jones 1994).

\section{Inseparability}

Perreault, Connon and McCarthy (2009:234) postulate that service quality is often not consistent because it is difficult to separate the service experience from the provider. Customer satisfaction and customer referrals of respective friends is often influenced by interactions with the organisation employees. With regard to tangible goods, they are first produced, sold and then consumed. On the other hand, services are sold and then produced and consumed simultaneously. Sometimes, the customer is present when the service is being produced and may even take part in the production process. Hence, the production of the service is dependent upon the individual employee in charge of it, the individual customer receiving it and the time taken to perform the service (Wilson, Zeithaml, Bitner \& Gremler 2008).

\section{Service Tangibles}

Certain service tangibles vary in terms of existence, design, relevance and service types. Services cannot be produced in a centralised location and consumed in decentralised locations. Hence, the service interaction between staff and customers is an integral part of the service delivery process (Palmer 2008). Kotler (2000) and Foster (2010) agree with this view and add that services are produced and consumed simultaneously. This means that the customer is present during the production of service which makes it impossible for the service provider to hide any quality shortfall (Lau, Akbar \& Gun Fie 1998). 


\section{Perishability}

Zeithaml, Bitner and Gremler (2006:321), maintain that services cannot be saved, stored, resold or returned. Furthermore, perishability in contrast to goods can be stored in inventory or resold another day, or even returned if the consumer is not happy. The fact that services cannot typically be returned or resold also implies a need for strong recovery strategy when things do go wrong (Wilson et al. 2008:19). Service involves action or performances (Lovelock \& Wirtz 2007:16). Because the services offered cannot be stored, warehoused or inventoried, supply and demand need to be managed by service organisations (Kotler 2000; Lamb et al. 2004; Lewis 2007).

\section{Nature of Service Quality}

Johns and Tyas (1996) argue that service quality is growing in importance in the marketing literature. The early attempts to specify and measure hospitality quality were only concerned with tangibles such as food and physical facilities. However, during the past decades, the intangible services are recognised as being increasingly important in the advanced competitive marketmogeneity and perishability), the quality of services is more difficult for consumers to evaluate than that of physical products (Kennedy 2003). The Service Delivery Improvement Programme (SDIP) of the SAPS defines service delivery as a programme designed to improve the quality of services rendered to the community. To improve the functioning of the CSC, the programme comprises of integrated plans at national, provincial, area and station level which align the priorities of the respective levels, setting out tasks, responsibilities, service standards, resources and time-frames (South African Police Service Act no 68 of 1995). Expectations have a direct effect on perceived quality. The perceived level is then compared to expectations, resulting in a gap or refudiation that may be either positive or negative.

According to Armstrong and Kotler (2010), a service's quality is difficult to judge because services are intangible, inseparable, perishable and heterogeneous. Service organisations thus use cues and images in their physical designs and promotions to make the benefits of a service more perceptible to clients (Perreault, Connon \& McCarthy 2009). In addition to these tangible efforts, culture is critical to good service. A service culture is one where an appreciation for good service exists. Providing goods services is expected, natural and one of the most important staffing activities as a service provider (Zeithaml, Bitner \& Gremler 2008). 
Customer satisfaction is determined by comparing the perceive service received against the service they expected or wished for, prior to receiving the service (Rust, Zahorik \& Keiningham 1995; Lotz 2009; Harris 2003). If the quality of service received is below the expected level, the customer will be dissatisfied. If the service is at the expected level, the quality is considered just 'satisfactory'. Where the perceived level exceeds the expected level of service, customers will be very satisfied, or 'delighted' (Kurtz \& Clow 2007). The only meaningful measure of customer service is the customer's perception of the quality of service offered - other measures are irrelevant to the client (Quintana 2006).

The aim of every service sector is consciously to minimise the discrepancy between service delivery and customer satisfaction. The ability of an organisation to determine the customer needs and to effectively meet the needs has a great impact on service quality. Storbacka, Storbacka, Strandvik, and Grönroos (1993) highlighted that service and relationship quality are antecedents to customer retention, and in a direct relationship with profit, since the cost of attracting new customers is higher than to retain existing ones.

\section{The Dimensions of Service Quality}

Quality is usually assessed as the difference between expected and perceived service levels across five dimensions (Fitzsimmons \& Fitzsimmons 2006), as follows.

\section{Tangibles}

Tangibility refers to the appearance of physical facilities, equipment, personnel and communication material (Wilson, Zeithaml, Bitner \& Gremler 2008; Bateson \& Hoffman 2011). Tangibles are visible evidence of the quality of the service customers receive that customers and are used to judge the service provider. For example, the condition of the physical premises (police stations) is used as a surrogate measure for the care and attention that they expect to receive from the service provider (Fitzsimmons \& Fitzsimmons 2006).

\section{Reliability}

Performing the promised service accurately and dependably means the provider can be relied upon (Wilson et al. 2008; Lovelock \& Wirtz 2011). If service is provided as expected, it will enhance the customer's perception of 
quality (Brink \& Berndt 2010). Reliability is the most critical component of a service, with the customer expecting the service to be accomplished timeously, consistently and error-free each time they interact with the service provider (Schneider \& White 2004).

\section{Responsiveness}

Responsiveness involves the service provider's willingness to serve the customers swiftly (Bateson \& Hoffman 2011). It accentuates promptness in handling customers' requests, complaints, and problems with attentiveness and speed. Customers become frustrated and angry if they perceive that they are being ignored. Making a customer wait for no good reason influences the perception of poor quality service (Perreault et al. 2009).

\section{Assurance}

Grönroos (2000) postulates that customers need to feel safe when making a transaction. The assurance dimension includes factors such as having the customers' best interest at heart, staff competence, politeness and respect, and effective communication. Arasli, Mehtap-Smadi and Katircioglu (2005:46) define assurance as the 'employees' knowledge, courtesy and ability to inspire trust and confidence in the customer'.

\section{Empathy}

Empathy involves caring and paying individual attention to customers. The essence of empathy is conveying, through personalized service, that customers are unique and special and that their needs are understood (Wilson et al. 2008). Empathy means understanding the clients' problems, doing things in their best interests and providing them with individual and personal attention; it implies approachability and sensitivity (Grönroos 2000). The significance of employees in service quality and service dimensions can be either positively or negatively influenced by staff actions. Hence, the role of staff in the service delivery process is critical (Lovelock \& Wright 2007):

- The appearance of employees, including how neatly they dress, is indicative of the tangible dimension of service quality.

- The reliability dimension of service quality is almost entirely controlled by employees and their actions. 
- Customers assess reliability by the actions of frontline employees, and their personal willingness to help customers.

- Assurance is created by employees communicating their personal credibility, thereby instilling trust in the customers.

- Empathy is provided by treating customers as individuals (Lovelock \& Wright 2007).

\section{Measuring Service}

Quality equality problem is indicated when a negative gap exists between the service level expected by a customer and the service level that customer perceived that they received. Such a negative gap could lead to negative wordof-mouth about the service being spread (Grönroos 2000). To close such a gap between performance and expectations, it is necessary to be able to measure service performance against expectations. According to Metters, King-Metters, Pullman and Walton (2006), the best way of understanding the nature and extent of this gap is by using the SERVQUAL instrument with the form's customers. The SERVQUAL approach has attracted attention in the public sector services (Donnelly, Kerr, Rimmer \& Shiu 2006). The SERVQUAL scale has been rigorously developed (LLosa \& Orginsher 2007) and has been used to measure service quality and the service quality gap by many researchers internationally (Fitzsimmons \& Fitzsimmons 2006). SERVQUAL asks respondents to rate their expectations and perceptions of a specific service (on a scale of from strongly disagree to strongly agree), for each of 22 pairs (expectations and perceptions) of statements about the five dimensions of service performance (Bruhn \& Georgi 2006). For example, the statements relate to the service provider's appearance and dress (tangibles), promises and dependability (reliability), willingness and promptness (responsiveness), knowledge and trustworthiness (assurance), and personal attention and caring (empathy) (Lee \& Ulgado 1997; Donnelly, Kerr, Rimmer \& Shiu 2006; Sarrico, Miguel, Ferreira \& Silva 2009).

\section{Importance of Employees in Service Quality}

Since all of the service dimensions can either be positively or negatively influenced by staff actions, the role of staff in the service delivery process is 
critical (Lovelock \& Wright 2007):

- The appearance of employees, including how neatly they dress, is indicative of the tangible dimension of service quality.

- The reliability dimension of service quality is almost entirely controlled by employees and their actions.

- Customers assess reliability by the actions of frontline employees, and their personal willingness to help customers.

- Assurance is created by employees communicating their personal credibility, thereby instilling trust in the customers.

- Empathy is provided by treating customers as individuals (Lovelock \& Wright 2007).

\section{Measuring Service Quality}

A quality problem is indicated when a negative gap exists between the service level expected by a customer and the service level that customer perceived that they received. Such a negative gap could lead to negative word-of-mouth about the service being spread (Grönroos 2000). To close such a gap between performance and expectations, it is necessary to be able to measure service performance against expectations. According to Metters, King-Metters, Pullman and Walton (2006) the best way of understanding the nature and extent of this gap is by using the SERVQUAL instrument with the form's customers. The SERVQUAL approach has attracted attention in the public sector services (Donnelly, Kerr, Rimmer \& Shiu 2006).

The SERVQUAL scale has been rigorously developed (LLosa \& Orginsher 2007) and has been used to measure service quality and the service quality gap by many researchers internationally (Fitzsimmons \& Fitzsimmons 2006). SERVQUAL asks respondents to rate their expectations and perceptions of a specific service (on a scale from strongly disagree to strongly agree), for each of 22 pairs (expectations and perceptions) of statements about the five dimensions of service performance (Bruhn \& Georgi 2006). For example, the statements relate to the service provider's appearance and dress (tangibles), promises and dependability (reliability), willingness and promptness (responsiveness), knowledge and trustworthiness (assurance), and personal attention and caring (empathy) (Lee \& Ulgado 1997: 41; Donnelly, Kerr, Rimmer \& Shi 2006). 


\section{Empirical Literature}

Whereas some researchers established a link between satisfaction and customer retention, others did not. For example, Fornell (1992) holds that high customer satisfaction will result in increased loyalty for the firm and that customers will be less prone to overtures from competition. Similarly, Jones and Sasser (1995) found that an increase in customer satisfaction produces a stronger effect on retention among customers who are at the high end of the satisfaction scale. But the difficulty has always been how to define the scale of satisfaction. However, Coyne (1989) concluded that the relationship between customer retention and customer satisfaction is weak when customer satisfaction is low, moderate when customer satisfaction is intermediate and strong when customer satisfaction is high. Thus, since different factors seem to affect the propensity to be loyal under the conditions of low and high satisfaction, it may be assumed that the form of the relationship between customer satisfaction and loyalty is different at different levels of satisfaction. Furthermore, the relationship between satisfaction and retention is neither simple nor linear which satisfied customers may defect (Jones \& Sasser 1995). As a result, there are no simple solutions for turning retention into profits. If it were easy, however, everyone would already be doing it (Keiningham et al. 2007; Vázquez-Casielles 2010). Despite the lack of consensus, they agreed that some relationship exists between customer satisfaction and its retention.

Simon, Seigyoung and Karen (2005) established that as customerorganisation relationships deepen; consumers increase their expertise in the firm's product line and industry and develop increased switching costs. Technical service quality is hypothesised to be a more important determinant of customer loyalty than functional service quality as expertise increases. Both technical and functional service quality is hypothesised to have a reduced relationship with customer loyalty as perceived switching costs increase. Three-way interactions between the main effects of service quality, customer expertise, and perceived switching costs yield additional insight into the change in relative importance of technical and functional service quality in customers' decision to be loyal. They concluded that some relationship exists between service quality and customer loyalty. Furthermore, Wan-Jin (2009) in examining the relationship between web-based service quality and customer loyalty revealed that service quality has a direct and positive effect on customer loyalty. The same relationship is demonstrated by Al-Rousan and Badaruddin 
(2010) in examining the relationship between service quality and customer loyalty in the Jordanian tourism industry. Bolton (1998) also noted that personal characteristics such as customers' gender (Cooil et al. 2007; Mittal \& Kamakura 2001) and age (Baumann, Burton \& Alliott 2005), which was revealed to affect customers' defection decisions considerably in various industries including financial and communication services as well as the auto industry. Lim and Kumar (2008) studied the effect of gender influence and customer retention and concluded that women are influenced by service quality more strongly than men. Men tend to focus on perceived economic value in retention decisions. Purchases by women is more influenced by interpersonal components of the service interactions than men.

\section{Research Methodology}

This study focused on describing the existing situation in three CSCs at one point in time, using a structured-questionnaire as the primary data collection instrument to gather information. The quantitative research method was adopted. The population comprised of persons 18 years and older, who had visited a SAPS CSC in the Kimberley cluster. The largest police station community service centres (Kimberley, Roodepan and Modderivier) were selected as data collection locations because they receive the greatest volume of complaints and are high crime stations.

The survey method was used to collect data (Hair, Bush \& Ortinau 2000) from the following SAPS CSCs:

- Kimberley station CSC -45

- Roodepan station CSC -35.

- Modderivier station CSC -20;

Section B included reasons for visiting the community service centre. In Section C, Community's expectation customer satisfaction of service delivery was measured by adapting a questionnaire format initiated by Parasuraman $e t$ al. (1988). This questionnaire has been psychometrically tested. The mentioned questionnaire is designed in accordance with the SERVQUAL Dimensions: Tangibility, Reliability, Responsiveness, Empathy and Assurance. Items on this section were measured on a Five-Point Scales; as shown below: 
- $1=$ Strongly Disagree, $(\mathrm{SDA})$

- 2 = Disagree, $(\mathrm{DA})$

- $3=$ Uncertain, (UD)

- 4 = Agree, $(\mathrm{A})$

- 5 = Strongly Agree, $(\mathrm{SA})$

Section D measured the perceptions of customers of the target group by adopting the Five-point Likert Scale: $1=$ Strongly disagree, 2 = Disagree, $3=$ Uncertain, 4 = Agree, 5 = Strongly agree.

\section{Results and Discussion}

The biographical profile of the sample is presented in below.

\section{Gender Distribution of Respondents}

Male respondents represented the majority of this group (54\%). The female respondents held the minority $(46 \%)$. The difference $(7 \%)$ indicates a relative even gender distribution. The gender variable was relevant to acquire a better understanding of the uniqueness of each individual. Statistically, it is important to note the different perceptions of the different genders within the organisation and community. No differentiation is made between transgender because every person is seen as an individual.

\section{Age Distribution of Respondents}

The highest number of respondents was in the age category: 35 and 39 (31\%), followed by age group 30 and $34(23 \%)$, and the age category of 45 and 50 $(12 \%)$ and $(7 \%) 51$ and older.

\section{Marital Distribution of Respondents}

The majority of the respondents (49\%) were single, while $28 \%$ were married. A minor segment of the respondents was divorced $(8 \%)$.

Extent of Satisfaction of Service Delivery by the SAPS 
John Modise, Derek Taylor \& Kishore Raga

Average communalities score of the dimensions.

\begin{tabular}{|l|l|l|}
\hline Dimensions & $\begin{array}{l}\text { Number of } \\
\text { items }\end{array}$ & Reliability \\
\hline Tangibles & 4 & Good \\
\hline Reliability & 5 & Good \\
\hline Responsiveness & 4 & Good \\
\hline Assurance & 4 & Good \\
\hline Empathy & 5 & Good \\
\hline Overall & $\mathbf{2 2}$ & Good \\
\hline
\end{tabular}

Source: Parasuraman (1988b)

The overall Cronbach alpha of the score revealed that the research instrument was statistically reliable with a high degree of consistency to score each dimension of the expectations and perceptions in the various categories.

Frequency table for customers' expectations of SAPS service delivery

\begin{tabular}{|l|l|l|l|l|l|}
\hline Dimension & $\begin{array}{l}\text { Strongly } \\
\text { agree }\end{array}$ & Agree & Uncertain & Disagree & $\begin{array}{l}\text { Strongly } \\
\text { disagree }\end{array}$ \\
\hline No & $\mathbf{1}$ & $\mathbf{2}$ & $\mathbf{3}$ & $\mathbf{4}$ & $\mathbf{5}$ \\
\hline Dimension 1: Tangibility \\
\hline C1 & 45 & 48 & 1 & 1 & 2 \\
\hline C2 & 43 & 50 & 1 & 2 & 1 \\
\hline C3 & 44 & 47 & 2 & 2 & 2 \\
\hline C4 & 47 & 44 & 1 & 2 & 3 \\
\hline Dimension 2: Reliability & 34 & 1 & 1 & 1 \\
\hline C5 & 60 & 34 & 0 & 1 & 2 \\
\hline C6 & 49 & 45 & 0 & 1 & 2 \\
\hline C7 & 66 & 28 & 1 & 1 & 1 \\
\hline C8 & 59 & 35 & 1 & 2 & 2 \\
\hline C9 & 35 & 58 & 0 & 1 & 2 \\
\hline Dimension 3: Responsiveness & 30 & 2 & 1 & 1 \\
\hline C10 & 62 & 30 & 0 & 2 & 2 \\
\hline C11 & 62 & 33 & 0 & 2 & 2 \\
\hline C12 & 63 & 29 & 0 & \\
\hline C13 & 36 & 57 & 0 & \\
\hline
\end{tabular}


Service Delivery from a South African Police Service Perspective

\begin{tabular}{|l|l|l|l|l|l|}
\hline Dimension 4: Assurance & \multicolumn{5}{l|}{$\mid$} \\
\hline C14 & 62 & 32 & 1 & 1 & 1 \\
\hline C15 & 60 & 34 & 1 & 1 & 1 \\
\hline C16 & 58 & 35 & 0 & 2 & 2 \\
\hline C17 & 55 & 39 & 1 & 1 & 1 \\
\hline Dimension 5: Empathy & 61 & 33 & 0 & 2 & 1 \\
\hline C18 & 63 & 29 & 1 & 2 & 2 \\
\hline C19 & 65 & 29 & 1 & 1 & 1 \\
\hline C20 & 59 & 33 & 2 & 2 & 1 \\
\hline C21 & 49 & 45 & 1 & 1 & 1 \\
\hline C22 & & & & \\
\hline
\end{tabular}

Frequency table for customers' perceptions of SAPS service delivery

\begin{tabular}{|c|c|c|c|c|c|}
\hline Dimension & $\begin{array}{l}\text { Strongly } \\
\text { agree }\end{array}$ & Agree & Uncertain & Disagree & $\begin{array}{l}\text { Strongly } \\
\text { disagree }\end{array}$ \\
\hline No & 1 & 2 & 3 & 4 & 5 \\
\hline \multicolumn{6}{|c|}{ Dimension 1: Tangibility } \\
\hline D1 & 61 & 30 & 2 & 2 & 2 \\
\hline D2 & 58 & 30 & 2 & 3 & 4 \\
\hline D3 & 68 & 24 & 2 & 1 & 2 \\
\hline D4 & 76 & 16 & 1 & 1 & 3 \\
\hline \multicolumn{6}{|c|}{ Dimension 2: Reliability } \\
\hline D5 & 73 & 20 & 1 & 2 & 1 \\
\hline D6 & 89 & 3 & 2 & 2 & 19 \\
\hline D7 & 76 & 14 & 1 & 2 & 1 \\
\hline D8 & 87 & 8 & 0 & 1 & 1 \\
\hline D9 & 87 & 8 & 0 & 1 & 1 \\
\hline \multicolumn{6}{|c|}{ Dimension 3: Responsiveness } \\
\hline D10 & 87 & 6 & 1 & 1 & 2 \\
\hline D11 & 57 & 36 & 1 & 1 & 2 \\
\hline D12 & 61 & 33 & 1 & 1 & 61 \\
\hline D13 & 58 & 35 & 2 & 1 & 1 \\
\hline \multicolumn{6}{|c|}{ Dimension 4: Assurance } \\
\hline D14 & 89 & 3 & 1 & 2 & 2 \\
\hline D15 & 93 & 1 & 1 & 1 & 1 \\
\hline
\end{tabular}


John Modise, Derek Taylor \& Kishore Raga

\begin{tabular}{|l|l|l|l|l|l|}
\hline D16 & 91 & 1 & 0 & 1 & 4 \\
\hline D17 & 78 & 13 & 2 & 2 & 2 \\
\hline Dimension 5: Empathy & 75 & 14 & 4 & 3 & 1 \\
\hline D18 & 86 & 1 & 4 & 4 & 2 \\
\hline D19 & 89 & 2 & 1 & 2 & 3 \\
\hline D20 & 85 & 5 & 3 & 2 & 2 \\
\hline D21 & 80 & 12 & 2 & 1 & 1 \\
\hline D22 & & & & \\
\hline
\end{tabular}

\section{Results}

Demographic factors were considered when viewing customer service quality. Lim et al. (2008) identified the significance of demographic characteristics to measure service quality. The researchers noted that demographic characteristics, inter alia, gender, age group and marital status can be considered to measure service quality (Kumar \& Lim 2008). Aspects such as reliability are acknowledged important factors in customer evaluation of service quality - customer loyalty (Hensher et al. 2003; Tyrinopoulos \& Aifadopoulou 2008).

The findings revealed that all the service quality dimensions have a significant relationship with customer loyalty. Zeithaml et al. (1996), observed a significant relationship between service quality and loyalty. Cronin and Taylor (1992) highlighted divergent results and did not find a direct relationship between quality and loyalty. However, they concluded that service quality had less of an impact on purchase intentions than consumer satisfaction and quality is an antecedent of the latter. For Cronin et al. (2000), this apparent contradiction is an indication that quality provides only a partial view of customer loyalty and that "models of consumers evaluations of services that consider individual variables or direct effects are likely to result in incomplete assessments of the basis of these decisions". The outcome supports the study by Oyeniyi and Abiodun (2008) who investigated the relationship between customer service quality and customer retention of mobile users in Nigeria. A moderately positive correlation $(0.506)$ between the variables $(\mathrm{r}=0.506, \mathrm{n}=$ $132, \mathrm{p}<0.01$ ) was revealed.

In summary, the study determined the effect of customer satisfaction of service quality provided by the SAPS to the community, and found that customer satisfaction of service quality delivered by SAPS was measured 
perceptually. The outcome revealed further the extent of customer satisfaction of the services of SAPS, the customers were 'satisfied' (Mean: 4.00-4.99) (reliability good). All the dimensions of the customers service included: tangibility, responsiveness, assurance, empathy, reliability. However, while empathy and reliability had a significant positive effect on customer satisfaction, none had a negative impact on customer satisfaction. The study in its findings proposed a conceptual model to explain the relationship between customer satisfaction and services delivered by the SAPS. The rationale for a model was based upon the argument by Zeithaml, Parasuraman, and Berry (1990:7), that a conceptual model in service quality enables management to identify quality problems and thus help in planning for the launch of quality improvement programmes thereby improving the efficiency, profitability and overall performance. The model adopted in this study is the original gap model by Parasuraman, Zeithaml and Berry in 1985, and refined in 1988 and 1991).

Gap 1 (positioning gap) - not knowing what customers are expecting from the service, usually due to insufficient marketing research or poor internal communication; failure to utilise feedback, or sometimes it's due to an organization's structure with too many levels of management.

Gap 2 (specification gap) - is concerned with the difference between what management believes the consumer wants and what the consumers expect the centre to provide. It is caused by the unwillingness or inability on the part of the organization to change the way a service is delivered in order to meet or exceed the customers' expectations.

Gap 3 (delivery gap) - is concerned with inability of staff to perform a service at the level expected by customer and as specified by the organization. This gap is related to the human elements involved in service delivery - the Staff. It can be caused by disgruntled or poorly motivated workers, where there is lack of proper supervision, or even the lack of skilled workers who are critical to the overall service quality experience.

Gap 4 (communication gap) - exists when the promises communicated by the provider do not match delivery usually caused by overzealous marketing that creates unrealistic expectation that cannot be met or exceeded. Subsequently the promises do not match delivery. 
John Modise, Derek Taylor \& Kishore Raga

Gap 5 (perception gap) - is the difference between the consumers' internal perceptions and expectations of the services. It is noted that Gaps 1 to 4 (lie within the control of the organization) can be analysed by providers to determine the cause(s) and change(s) to be implemented to reduce or eliminate Gap 5.

\section{Figure 1: Service Quality Model}

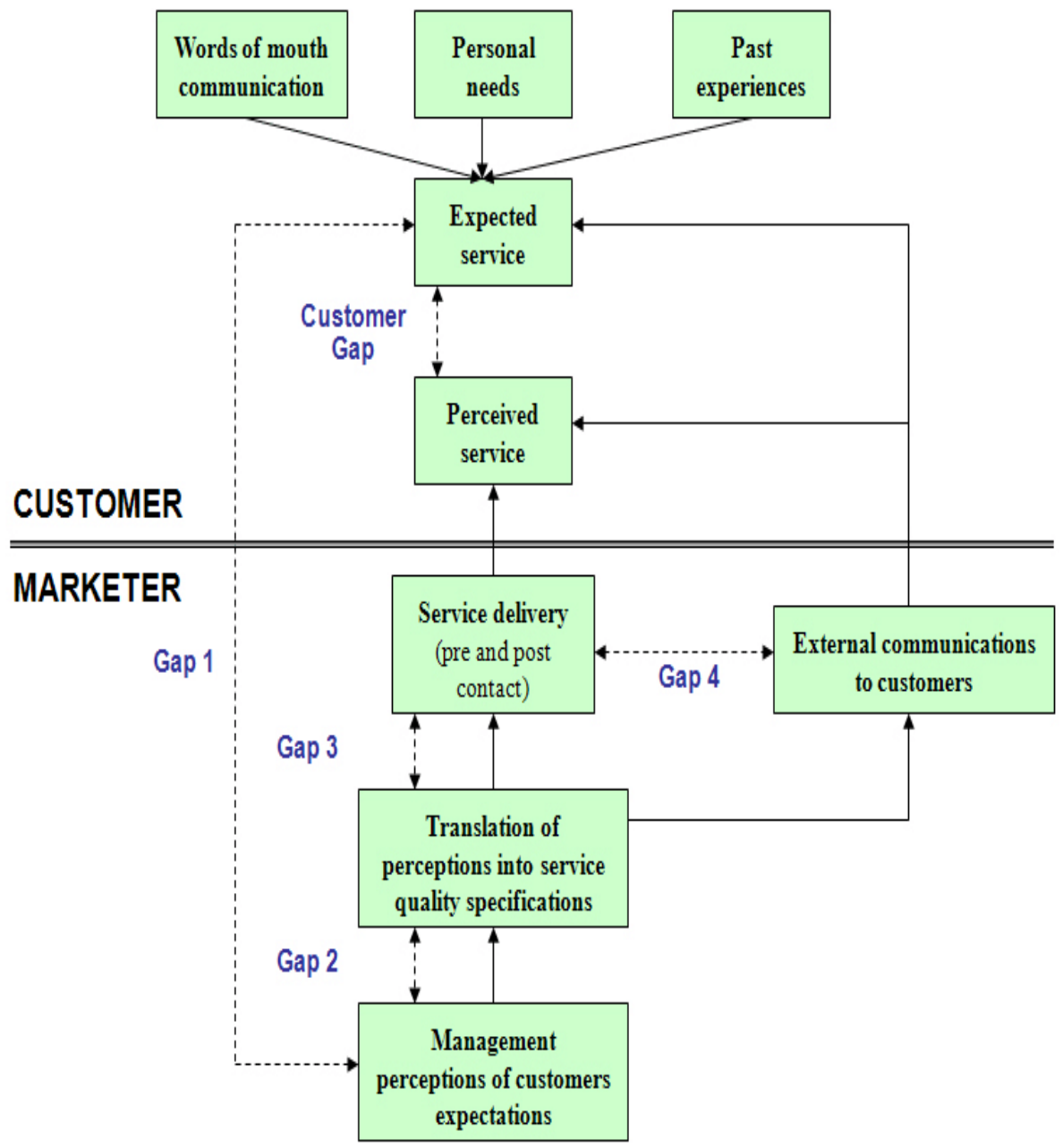


To operationalise service quality using this model, a 24 -item scale comprising of the five dimensions: reliability, responsiveness, tangibles, empathy and assurance was used to identify where gaps in the service existed and to what extent. The framework pre-supposes that service quality is the customer's thinking that they are getting better service than expected. It's worth noting that both sides of the gap are in the customers mind (manifesting the service quality attributes). But as it is with any research tool, researchers have expressed concerns and criticism of the original instrument including: the five dimensions being unstable across recreational services (Shonk 2006), domains of service quality may be factorially complex in some and very simple and unidimensional in others (Babakus \& Boller 1992:253), failure to draw on other disciplines such as psychology, social sciences and economics (O'Neil \& Palmer 2004:433). These remarks notwithstanding, the researcher agrees with Parasuraman (1991) that this is a good diagnostic tool hence suggests that for this particular study, the instrument was customized for the fitness sector including additional relevant questions as proposed by (Brown, Garland, Jeffrey, Jameson \& Leroi 1993:285).

drawn:

Based on the findings of the study, the following conclusions can be

- The customers were satisfied with the quality of service delivered by the SAPS.

- Of the service quality dimension, reliability, empathy, tangibility, responsiveness and assurance had a significant positive effect on customers. None had a negative effect on customers and rated 4 and above.

\section{Recommendations}

Based on findings of the study, the following recommendations were proposed.

- The SAPS should have measures of performance based on rigorous clients' satisfaction outcomes. The measures should be monitored regularly by an independent auditor such as a market research company which should be recruited to monitor clients' and SAPS staff. This would close the gap between actual performance and expectations. 
- Quality service must start with education: the SAPS must invest in training the employees at all levels to improve skills in order to facilitate changes in behaviour and attitude. A client service course must be conducted among SAPS members, particularly those who work at the Community Service Centre. Moreover, attendance must be compulsory.

- SAPS must develop a new unit - "client care units". The unit head office should be based at the provincial office. Each police station will have two client care members to ensure that all complaints are managed properly, and identify the person responsible for the submission of a report at the end of each month to the provincial offices. This could assist the organisation to establish the number of complaints they receive annually; how many were resolved; and how many remain outstanding and need to be attended to. Two members must personally visit or call all unhappy clients and attend to their complaints.

\section{Conclusion}

The ultimate determinant of SAPS performance is perhaps general public opinion. Irrespective of how good the department might appear in terms of statistics, it fails in democratic terms if the community is not satisfied. Any perception from the broader community of the SAPS' inability to provide efficient services to citizens should be addressed by management. In this regard, the lockdown measures imposed on South Africans and enforced by the SAPS and the military due to COVID-19, will influence public opinion on the role of law enforcement agencies in the country. Public perception cannot be easily reversed by means of the normal organisational change methods or good public relations exercises. Rather, they require radical change intervention. Part of the leadership challenge in any police department is to implement strategies to improve the public's perceptions on performance. The apparent increasing levels of violent crime such as murder, robbery, rape and other forms of aggravated murder and robbery have become a recurring theme in contemporary South Africa. The SAPS needs leaders that can devise strategies, identify weaknesses, and fix problems where policy fails, as well as demonstrate courage, foresight, decisive leadership, and clarity of vision to enhance services to the South African citizenry. 


\section{References}

Al-Rousan, M.R. \& M. Badaruddin 2010. Customer Loyalty and the Impacts of Service Quality: The Case of Five-star Hotels in Jordan. International Journal of Business, Economics, Finance and Management Sciences, 2,3. Anderson, E. \& M.W. Sullivan 1993. The Antecedents and Consequences of Customer Satisfaction for Firms. Marketing Science 12,2: 125 - 143. https://doi.org/10.1287/mksc.12.2.125

Arasli, H., A. Mehtap-Smadi \& S.T. Katircioglu 2005. Customer Service Quality in the Greek Cypriot Banking Industry. Journal of Managing Service Quality 15,1: 41 - 56.

https://doi.org/10.1108/09604520510575254

Babakus, E. \& G.W. Boller 1992. An Empirical Assessment of the SERVQUAL Scale. Journal of Business Research 24: 253 - 268. https://doi.org/10.1016/0148-2963(92)90022-4

Bateson, J. E. G. \& K.D, Hoffman. 2011. Services marketing. 4th ed. Australia: South-Western Cengage Learning.

Baumann, C, S. Burton, \& G, Alliott 2005. Determinants of Customer Loyalty and Share of Wallet in Retail Banking. Journal of Financial Services Marketing 9,3: 231 - 248.

Berg, J. 2006/2007. Civilian Oversight of Police in South Africa: From the ICD

to the IPID. Available at: https://doi.org/10.1080/15614263.2013.767094

(Accessed on 04 June 2020).

Bolton, R.N. 1998. A Dynamic Model of the Duration of the Customer's Relationship with a Continuous Service Provider: The Role of Satisfaction. Marketing Science 17,1: 45 - 65.

Brink, A. \& A. Berndt 2010. Customer Relationship Management and Customer Service. Johannesburg: Juta

Brown, M.R., C.D. Garland, S.W. Jeffrey, I.D. Jameson \& J.M. Leroi 1993. The Gross and Amino Acid Compositions of Batch and Semi-continuous Cultures of Isochrysis sp. (clone TISO), Pavlova lutheri and Nannochloropsis oculata. Journal of Applied Phycology 5,3: 285 - 296.

https://doi.org/10.1007/BF02186231

Bruhn, M. \& D. Georgi 2006. Services Marketing: Managing the Service Value Chain. London: Pearson Education.

Burger, J. 2013. The National Development Plan can Improve Policing in South Africa. Available at: 
John Modise, Derek Taylor \& Kishore Raga

https://issafrica.org/iss-today/the-national-development-plan-canimprove-policing-in-south-africa (Accessed on 04 June 2020).

Burger, J. 2011. Strategic Perspectives on Crime and Policing in South Africa. Pretoria: Van Schaik.

Chowdhary, N. \& M. Prakash 2001. Service Quality: Revisiting the Two

Factors Theory. In Proceeding of The First International Conference on

Electronic Business (2001). Hong Kong, December 19-21.

https://doi.org/10.1016/S1013-7025(09)70020-X

Cooil, D., D. Bruce, L. Timothy, P. Keiningham, A. Lerzan \& M. Hsu 2007.

A Longitudinal Analysis of Customer Satisfaction and Share of Wallet:

Investigating the Moderating Effect of Customer Characteristics. Journal

of Marketing 71,1:67 - 83. https://doi.org/10.1509/jmkg.71.1.067

Coyne, K. 1989. Beyond Service Fads Meaningful Strategies for the Real

World. Sloan Management Review 30: 69 - 76.

Dhurup, M., P.C. Singh \& J. Surujlal 2006. Customer Service Quality at Commercial Health and Fitness Centres. South African Journal for Research in Sport 28,2: 39 - 54.

https://doi.org/10.4314/sajrs.v28i2.25942

Donnelly, M., N.J. Kerr, R. Rimmer \& E.M. Shiu 2006. Assessing the Quality of Police Services using SERVQUAL. Policing: An International Journal of Police Strategies \& Management 9,1: 92 - 105.

https://doi.org/10.1108/13639510610648502

Edvardsson, B. \& B. Enquist. 2011. The Service Excellence and Innovation Model: Lessons from IKEA and other Service Frontiers. Total Quality Management \& Business Excellence 22,5: 535 - 551.

https://doi.org/10.1080/14783363.2011.568242

Fitzsimmons, J. A. \& M. J. Fitzsimmons. 2008. Service Management:

Operations, Strategy, Information Technology. New York: McGraw-Hill. Fornell, C. 1992. A National Customer Satisfaction Barometer: The Swedish

Experience. Journal of Marketing 55: 6 - 21.

Foster, T. 2010. Managing Quality - Integrating the Supply Chain. $4^{\text {th }}$ Edition.

New Jersey: Pearson Prentice Hall.

Ghobadian, A. Speller, S. \& M. Jones. 1994. Service Quality Concepts and

Models. International Journal of Quality \& Reliability Management, 11,9: 43 - 66.

https://doi.org/10.1108/02656719410074297

Grönroos, C. 1988. Service Quality: The Six Criteria of Good Service Quality: 
Reviews of Business. New York: St John's University Press.

Hair, J.F, R.P. Bush \& D.J. Ortinau 2000. Marketing Research: A Practical Approach for the New Millennium. USA: McGraw-Hill.

Harris, E. K. 2003. Customer Service: A Practical Approach. $3^{\text {rd }}$ Edition. New Jersey: Prentice-Hall.

Hensher, D., A. Stopher \& P. Bullock 2003. Service Quality - Developing a Service Quality Index in the Provision of Commercial Bus Contracts. Transportation Research Part A: Policy and Practice 37: 499-517. https://doi.org/10.1016/S0965-8564(02)00075-7

Independent Police Investigative Directorate 2017. Independent Police Investigative Directorate Annual Performance Plan. Pretoria: Government Printer.

Jakoet-Salie, A. 2018. Co-production of Trust for Effective Local Governance.

PhD Thesis. Nelson Mandela University, Port Elizabeth.

Johns, N. \& P. Tyas. 1996. The Use of Service Quality Theory to Differentiate between Food Service Outlets. Service Industry Journal 16,3: 321 - 346. https://doi.org/10.1080/02642069600000031

Jones, T. O. \& W.E.J. Sasser. 1995. Why Satisfied Customers Defect. Harvard Business Review 73: 88 - 99.

Keiningham, T., L. Aksoy, L. Cooil, B. \& T.W. Andreassen 2008. Linking Customer Loyalty to Growth. MIT Sloan Management Review 49,4: 50 57.

Kennedy, J. 2003. Services Marketing - A Managerial Approach. Melbourne: Wiley.

Kotler, P. \& G. Armstrong. 2010. Principles of Marketing. $13^{\text {th }}$ Edition. Upper Saddle River: Pearson.

Kotler, P. 2000. Marketing Management. The Millennium Edition. New Jersey: Prentice Hall.

Kumar, A. \& H. Lim. 2008. Age Differences in Mobile Service Perceptions: Comparison of Generation Y and Baby Boomers. Journal of Service Research 22,7: 568 - 577.

https://doi.org/10.1108/08876040810909695

Kurtz, D.L. \& K.E. Clow. 2007. Service Marketing. $3^{\text {rd }}$ Edition. New York: John Wiley \& Sons, Inc.

Lamb, S., A. Walstab, R. Teese, M. Vickers \& R. Rumberger 2004. Staying on at School: Improving Student Retention in Australia. Brisbane: Department of Education and the Arts, the State of Queensland. 
Lampbrechts, D. S. \& J.H. Prinsloo 1996. The Powers and Functions of the South African Police Service - A 'New' Socio-legal Perspective. Acta Criminologica: Southern African Journal of Criminology 9,2: 85 - 89.

Lau, G. \& S. Lee 1999. Consumers' Trust in a Brand and Link to Brand Loyalty. Journal of Market Focused Management 4: 341 - 370.

https://doi.org/10.1023/A:1009886520142

Lee, M. \& F.M. Ulgado. 1997. Consumer Evaluation of East Food Service. Journal of Service Marketing 11,1: 41.

https://doi.org/10.1108/08876049710158358

Lewis, R.C. \& B.H. Booms 1983. The Marketing Aspects of Service Quality. In Berry, L.L., G. Shostack \& G. Upah (eds.): Emerging Perspectives in Service Marketing. Chicago, IL: American Marketing Association.

LLosa, S. \& C. Orsingher. 2007. Service Industry Management. International Journal of Service Industry Management 18,5: 474. https://doi.org/10.1108/ijsim.2007.08518eaa.001

Lotz, C. 2009. Customer Service Quality at Selected Commercial Health and Fitness Centres in KwazuluNatal. Unpublished dissertation Durban University of Technology.

Lovelock, C. \& J. Wirtz 2007. Services Marketing: People, Technology,

Strategy. $6^{\text {th }}$ Edition. New Jersey: Pearson Prentice Hall.

Metters, R., K. King-Metters, M. Pullman \& S. Walton 2006. Successful Service Operations Management. International Edition. Ann Arbor, MI: Edwards Brothers.

Milton, T. \& J.R. A. Astroff. 1998. Convention Sales and Services. $5^{\text {th }}$ Edition. New Jersey: Waterbury Press.

Mittal, M., J. Vikas \& W.A. Kamakura 2001. Satisfaction, Repurchase Intent, and Repurchase Behavior: Investigating the Moderating Effect of Customer Characteristics. Journal of Marketing Research 38, February: $131-142$.

https://doi.org/10.1509/jmkr.38.1.131.18832

Ngcamu, B. S. 2019. Exploring Service Delivery Protests in Post-apartheid South African Municipalities: A Literature Review. The Journal for Transdisciplinary Research in Southern Africa 15,1: 9.

https://doi.org/10.4102/td.v15i1.643

O'Neill, M. \& A. Palmer 2004. Cognitive Dissonance and the Stability of Service Quality Perceptions. Journal of Services Marketing 18,6: 433 449. https://doi.org/10.1108/08876040410557221 
Palmer, A. 2008. Principles of Services Marketing. $5^{\text {th }}$ Edition. Maidenhead, Berkshire: McGraw-Hill.

Parasuraman, A., V.A. Zeithaml \& L.L. Berry 1985. A Conceptual Model of Service Quality and its Implications for Future Research. Journal of Marketing 49,4: 41 - 50. Available at:

http://proxy.library.lincoln.ac.uk/login?url=http://search.ebscohost.com/l ogin.aspx?direct $=$ true $\& \mathrm{db}=\mathrm{bth} \& \mathrm{AN}=5001773 \&$ site $=$ edslive\&scope $=$ site (Accessed on 14 October 2020).

https://doi.org/10.1177/002224298504900403

Perreault, W.D., J.P. Connon \& E.J. McCarthy 2009. Basic Marketing: A Marketing Strategic Planning Approach. $17^{\text {th }}$ Edition. McGraw-Hill: New York.

Phillips, J. 2002. The Effect that a Performance and Development System can have on Customer Service Delivery: A Case Study. Unpublished MBA Dissertation, Milpark Business School, Johannesburg.

Quintana, J. 2006. The Greatest Blind Spot: Customer Perception. Available: http://www.mycustomer.com/cgibin/item.cgi?id=132560\&u=pnd\&m=ph nd (Accessed on 24 October 2020).

Robinson, C. 2002. Real World Research. $2^{\text {nd }}$ Edition. Oxford: Blackwell. Roelofse, C.J. 2017. Service Delivery Protests and Police Actions in South Africa: What are the Real Issues? Journal of Public Administration and Development Alternatives (JPADA) 2,2: 1 - 14.

Rust, R.T. A.J. Zahorik \& T.L. Keiningham 1995. Return on Quality (ROQ):

Making Service Quality Financially Accountable. Journal of Marketing 59,April: 58 - 70. https://doi.org/10.1177/002224299505900205

Sarrico, C.S., L. Miguel, D.F.F. Ferreir \& L.F.C. Silva 2013. POLQUAL Measuring Service Quality in Police Traffic Services. International Journal of Quality and Service Sciences 5,3: 275 - 289.

https://doi.org/10.1108/IJQSS-12-2012-0024

Schneider, B. \& S.S. White 2004. Service Quality: Research Perspectives. Thousand Oaks, CA: Sage Publications Inc.

Sekaran, U. \& R. Bougie. 2013. Research Methods for Business: A Skillbuilding Approach. $6^{\text {th }}$ Edition. Wiley: Chichester.

Shonk, D.J. 2006. Perceptions of Service Quality, Satisfaction and the Intent to Return among Tourists Attending a Sporting Event. Unpublished PhD. Simon, J.B., A. Seigyoung \& S. Karen 2005. Customer Relationship Dynamics: Service Quality and Customer Loyalty in the Context of 
Varying Levels of Customer Expertise and Switching Costs. Journal of the Academy of Marketing Science 33,2: 169 - 183.

https://doi.org/10.1177/0092070304269111

Sonderling, N.E. 2003. Scoping and developing the potential for SAPS online service delivery. Unpublished dissertation submitted to the Department of Information Science, University of Pretoria.

South Africa 1995. The South African Police Services Act 68 of 1995. Pretoria: Government Printer.

South Africa 1997. South African Police Service Code of Conduct (SAPS). Pretoria: Government Printer.

South Africa 2011. The National Development Plan. Pretoria: Government Printer.

SAPS 2000. National instruction 1/2000. The Service Delivery Improvement Programme.

South African Police Service (SAPS) 2002. South African Police Service National Strategy. Pretoria: Government Printer.

South African Police Service (SAPS) 2006a. National instruction 1/2006. The Service Delivery Improvement Programme. Pretoria: Government Printer. South African Police Service (SAPS) 2006b. South African Police Service Journal. Pretoria: Government Printer.

South African Police Service (SAPS) 2006c. South African Police Service Work Committee. Pretoria: Government Printer.

South African Police Service (SAPS) 2013. South African Police Service

Delivery Improvement Plan. Pretoria: Government Printer.

South African Police Service (SAPS). 2014/19. Strategic Plan. Pretoria: Government Printer.

South Arica 1996. The Constitution of the Republic of South Africa (1996). Pretoria: Government Printer.

Storbacka, K., T. Strandvik \& C. Grönroos 1994. Managing Customer Relationships for Profit: The Dynamics of Relationship Quality. International Journal of Service Industry Management 5,5: 21 - 38.

https://doi.org/10.1108/09564239410074358

The Daily Sun Newspaper 2017. Report by the former Minister of Police $\mathrm{Mr}$ Fikile Mbalula, October 2017.

Van der Merwe, J., J. van Graan \& W.I. Ukpere 2013. Effective Service Delivery: A Leadership Challenge for Policing. Mediterranean Journal of Social Sciences 4,14: 627. 
https://doi.org/10.5901/mjss.2013.v4n14p627

Vázquez-Casielles, R., L. Suárez Álvarez \& A.M. Díaz Martín 2010. Perceived Justice of Service Recovery Strategies: Impact on Customer Satisfaction and Quality Relationship. Psychology \& Marketing 27,5: 487 - 509. https://doi.org/10.1002/mar.20340

Wan-Jin, Leu. 2009. The Relationship between Web-based Service Quality AND Customer Loyalty. Doctoral dissertation. Nova Southeastern University. NSU Works, H. Wayne Huizenga School of Business and Entrepreneurship 59. Available: https://nsuworks.nova.edu/hsbe_etd/59 (Accessed 12 January 2020).

Wilson, A. V.A. Zeithaml, M.J. Bitner \& D.D. Gremler 2008. Services Marketing. McGraw-Hill Education: London.

Zeithaml, V.A., M.J. Bitner \& D.D. Gremler 2006. Service Marketing; Integrating Customer Focuses across the Firm. $4^{\text {th }}$ Edition. McGraw-Hill: New York.

Zimmerman, A. \& J. Blythe 2013. Business to Business: A Global Perspective. $2^{\text {nd }}$ Edition. New York: Routledge.

Zeithaml, V.A., A. Parasuraman \& L.L. Berry 1990. Delivering Quality Service: Balancing Customer Perceptions and Expectations. New York: The Free Press.

John Modise

$\mathrm{PhD}$ Candidate

Nelson Mandela University johnmodise3@gmail.com

Derek Taylor Professor

Nelson Mandela University Derek.Taylor@mandela.ac.za

Kishore Raga Professor \& Research Associate

Nelson Mandela University Kishore.Raga@mandela.ac.za 